\title{
Somatotrophic Diabetes: Insulin Release Responses to Arginine and Glucagon in Dogs
}

\author{
J. Campbell, J. Pierluissi, and G. R. Green \\ Department of Physiology, University of Toronto, Toronto, Ontario, Canada
}

\begin{abstract}
Summary. Growth hormone injected daily in 6 dogs for 6 days caused a 20 -fold elevation in fasting serum immunoreactive insulin (IRI) without appreciable change in serum glucose in 1 day. In the somatotrophic diabetes that occurred after 2 days, the hyperinsulinaemia was maintained and the serum IRI/glucose ( $/ / G)$ ratio declined from the early high level but remained elevated. During this treatment, in response to glucose infusion, the rise in serum IRI above the initially high fasting level was 16 times the normal. In response to glucagon, the rise in IRI was twice the normal and the rise in glucose was more prolonged, resulting in a decline in the $\mathrm{I} / \mathrm{G}$ ratio. In response to arginine infusion, the rise in serum IRI was 8 times the normal and the rise in the $\mathrm{I} / \mathrm{G}$ ratio was twice normal. Following a meal, the rise in serum IRI was 8 times the normal. Thus, with growth hormone treatment the insulin secretory responses to these stimulating factors were magnified over the already elevated fasting level of secretion. The insulin content of the pancreas was reduced to less than $10 \%$ of normal by growth hormone treatment for 6 days, due apparently to elevation of the rate of secretion over the rate of formation of insulin.
\end{abstract}

Key words: Growth hormone, somatotrophic diabetes, diabetes, glucagon, arginine, serum insulin, immunoreactive insulin, hyperinsulinaemia, insulin secretion, insulin-secretory responses, augmentation of insulin secretion.

Growth hormone enhances pancreatic islet growth [1] and the formation and secretion of insulin in the rat $[2,3,4]$. Growth hormone also produces diabetes (somatotrophic diabetes) in the cat [5] and dog [6].
These apparently conflicting pancreotrophic and diabetogenic effects may be linked by the findings that growth hormone treatment in the dog caused hyperinsulinaemia that persisted in the subsequently induced somatotrophic diabetes, and also augmented the rises in serum immunoreactive insulin (IRI) elicited by injection of glucose and the ingestion of a meal $[7,8]$. These effects were associated with enhanced secretion of insulin under basal conditions [9] and also under stimulation by factors that cause insulin release [10]. Further relations between growth hormone and insulin have been reviewed [11, 12]. Our objective was to test the responses of the pancreatic islets to the challenges of glucagon and arginine in somatotrophic diabetes, as outlined in a preliminary report [13].

\section{Materials and Methods}

Six adult male dogs were housed in metabolism cages under practically constant environmental conditions. The daily food of $425 \mathrm{~g}$ canned meats with other ingredients (Romar 90) and $200 \mathrm{~g}$ of dog chow (Purina), was divided into two meals that were given morning and afternoon during over a year of residence in the laboratory (calculated totals: protein $84 \mathrm{~g}$, fat $27 \mathrm{~g}$ and carbohydrate $140 \mathrm{~g}$ daily). Food intake was practically ad libitum since occasionally some food was left uneaten. Mean body weight increased gradually from $13.5 \pm 1.3$ to $17.9 \pm 1.1 \mathrm{~kg}$ in about 300 days, then remained unchanged. Following growth hormone treatment the abdominal adipose tissue was judged by visual examination to contain a much greater amount of fat than that present in 3 normal dogs that were given the same diet for only 6 days. This adiposity probably developed in this control period, in which the dogs became accustomed, with no apparent disturbance, to the experimental procedures.

The tests were performed without anaesthesia about $17 \mathrm{~h}$ after the evening meal and were preceded by the withdrawal of two $6 \mathrm{ml}$ samples of venous blood. Glucose $1.0 \mathrm{~g} / \mathrm{kg}$ body weight was injected intravenously (IV) within a minute as a solution of glucose $(50 \% \mathrm{~W} / \mathrm{V}$ in $0.154 \mathrm{~mol} \mathrm{NaCl} / 1)$ after allowing ample time for equilibration of the $a$ and $b$ anomers. The effects of a normal 
meal were tested by sampling venous blood at intervals after ingestion. The test was performed in 5 dogs during growth hormone treatment as one of the six did not eat the meal promptly at the time of the test. Glucagon (Lilly, Lot 258-234-B-167-1,1.0 mg/ml in $0.154 \mathrm{~mol} \mathrm{NaCl} / \mathrm{l})$ was injected IV $(0.1 \mathrm{mg} / \mathrm{kg}$ body weight) within 5 seconds. Arginine (L-arginine monochloride, $40 \% \mathrm{~W} / \mathrm{V}$ in $0.154 \mathrm{~mol} \mathrm{NaCl} / \mathrm{l}$ ) was injected IV within a minute, in the dose of $0.4 \mathrm{~g} / \mathrm{kg}$ body weight. These tests were performed in the control period and were repeated in the treatment period at $1,2,3$ and 5 days respectively from the first injection of growth hormone. The dogs served as their own controls in these tests.

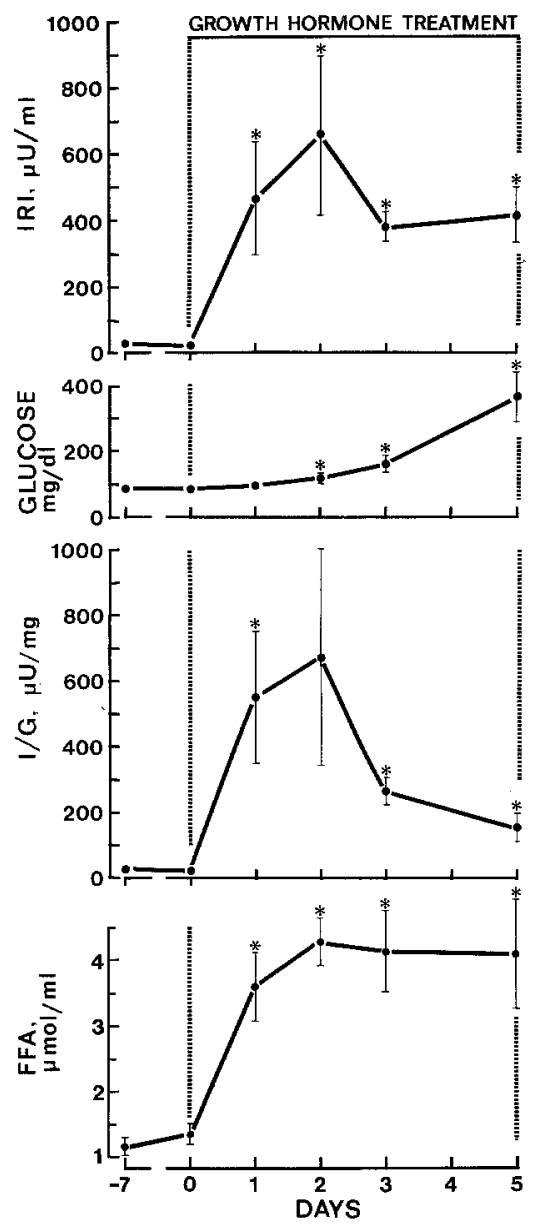

Fig. 1. Effects of daily treatment with growth hormone in 6 dogs on fasting serum IRI, glucose, I/G ratio and FFA. A value with an asterisk $\left({ }^{*}\right)$ placed above it is significantly different from the pretreatment value at zero minutes ( $P$ range $<0.05-<0.001$ )
Bovine growth hormone (Connaught Medical Research Laboratories, Lot $100-1,10 \mathrm{mg} / \mathrm{ml}$ in $0.154 \mathrm{~mol} \mathrm{NaCl} / 1$ at $\mathrm{pH} 8$ ) was injected subcutaneously twice daily at meal times, in the dosage of $2.0 \mathrm{mg} / \mathrm{kg}$ body weight for the first two days and $1.0 \mathrm{mg} / \mathrm{kg}$ for the remaining 4 days. This preparation had high growth promoting activity by the tibia test [14] and contained only traces of other pituitary hormones. After electrophoresis on $7 \%$ polyacrylamide gel, pH 8.9 [15] the band pattern was similar to that of growth hormone $\mathrm{NIH}, \mathrm{HG} \mathrm{B}-16$.

In serum were determined IRI by a double antibody method [16], glucose by use of glucose oxidase (Sigma No. 6125) and a polarographic electrode [17] and free fatty acids (FFA) by a colorimetric method [18]. In urine, glucose was measured by Benedict's method.

At 6 days from the first injection of growth hormone, the dogs were anaesthetised by IV sodium pentobarbital $(25-30 \mathrm{mg} / \mathrm{kg}$ body weight). Blood was removed through a carotid cannula and the pancreas was excised within $15 \mathrm{~min}$. Insulin was extracted from the pancreatic tissue and the extract was partially purified to the end of step 3 [19]. The precipitate was suspended in $0.154 \mathrm{~mol}$ $\mathrm{NaCl} / 1$, sufficient $1 \mathrm{~N} \mathrm{HCl}$ was added to give a clear solution at $\mathrm{pH}$ 2-4 and the volume was adjusted to $25 \mathrm{ml}$. After suitable dilution of this solution with phosphate buffer $(0.04 \mathrm{~mol} / 1, \mathrm{pH} 7.4$, containing $0.154 \mathrm{~mol} \mathrm{NaCl} / \mathrm{l}$ and $1.0 \mathrm{~g}$ bovine plasma albumin/l) IRI was determined. As control, the pancreatic IRI of 3 normal dogs that were given the dietary regimen for only 6 days was determined: clearly, a better control would have been the insulin content of the pancreas in a group of normal, untreated dogs kept for the same length of time and given the same tests as the growth hormone treated dogs.

Values are presented as means ( \pm SEM, shown in Figures as vertical strokes). The probability (P) of the difference between means was calculated by Student's t test [20]: differences were considered to be significant for $\mathrm{P}<0.05$.

\section{Results}

The growth hormone treatment (Fig. 1) caused a 20fold increase in the fasting serum IRI in one day and high fasting values were maintained thereafter. The serum glucose level increased by $40 \%$ at day 2 $(\mathrm{p}<0.05)$ then rose to about 2 -fold and 4-fold the initial value on days 3 and $5(\mathrm{P}<0.025$ and $<0.005$, respectively). Consequently the IRI/glucose (I/G) ratio increased approximately in proportion to the IRI in the first 2 days then declined but remained above normal. Serum FFA rose to a high level at 1 day and remained elevated. Urine volume increased and glucose was excreted on days 2-6 (Table 1).

Table 1. Effects of daily treatment with growth hormone in 6 dogs

\begin{tabular}{lccccccc}
\hline & \multicolumn{7}{l}{ Days of Growth Hormone Treatment } \\
\cline { 2 - 7 } & 0 & 1 & 2 & 3 & 4 & 5 & $6^{\mathrm{a}}$ \\
\hline Body weight, $\mathrm{kg}$ & $18.0 \pm 0.9$ & $18.2 \pm 1.0$ & $18.5 \pm 1.0$ & $18.5 \pm 1.0$ & $18.7 \pm 1.0$ & $18.5 \pm 1.0$ & $18.2 \pm 1.0$ \\
Urine volume, $\mathrm{ml}$ & $142 \pm 42$ & $174 \pm 63$ & $575 \pm 128$ & $673 \pm 180$ & $886 \pm 260$ & $1100 \pm 320$ & $1490 \pm 543$ \\
$\mathrm{p}^{\mathrm{b}}$ & & 0 & $<0.01$ & $<0.025$ & $<0.025$ & $<0.025$ & $<0.05$ \\
Sugar excretion, $\mathrm{g}$ & 0 & & $12 \pm 5$ & $19 \pm 5$ & $28 \pm 11$ & $26 \pm 9$ & $43 \pm 27$ \\
\hline
\end{tabular}

a Values in 5 dogs on day 6

${ }^{b}$ Probability of difference from the urine volume in the control period (day 0) 
Anorexia, vomiting and lethargy were observed in two of the dogs: despite the reduction in dosage of growth hormone, one of these dogs died following the final injection.

\section{Response to Glucose}

In the normal state, IV glucose administration (Fig. 2) was followed by a rise in serum IRI (at 0,15 , 30 , and $60 \mathrm{~min}$ the values were $38 \pm 5,160 \pm 43$, $120 \pm 37$ and $41 \pm 7 \mu \mathrm{U} / \mathrm{ml}$ respectively). Serum glucose values at the above intervals were $66 \pm 2$, $310 \pm 11,155 \pm 21$ and $65 \pm 5 \mathrm{mg} / \mathrm{dl}$. The $\mathrm{I} / \mathrm{G}$ ratio did not change appreciably in this response (at $0 \mathrm{~min}$ $57 \pm 7$ and at $15-20 \mathrm{~min}$ range $52 \pm 14-85 \pm$ $26 \mu \mathrm{U} / \mathrm{mg}$ ).

On repeating the test 1 day after the first injection of growth hormone (Fig. 2) the IRI rise was vastly greater than in the control period (at the above intervals serum IRI was $468 \pm 172,2400 \pm 321$, $1370 \pm 306$ and $827 \pm 244 \mu \mathrm{U} / \mathrm{ml}: \mathrm{P}$ at 15 and 30 $\min <0.001$ and $<0.05$ ). The rise in serum glucose was also high and prolonged. The $\mathrm{I} / \mathrm{G}$ ratio did not depart significantly from the initially high fasting level, however (at $0 \min 549 \pm 202$ and at $15-120$ min range $439 \pm 102-560 \pm 231 \mu \mathrm{U} / \mathrm{mg}$ ). During growth hormone treatment the fasting serum IRI was 12 times normal; at $15 \mathrm{~min}$ after glucose infusion the rise in serum IRI was 16 times normal and the rise in serum glucose was 1.6 times normal (Table 2).

FFA decreased following the administration of the glucose load: the decline at $30 \mathrm{~min}$ from the initially high level was more marked during the growth hormone treatment than in the control period $(-1.23 \pm 0.60$ and $-0.72 \pm 0.19 \mu \mathrm{mol} / \mathrm{ml} \mathrm{respec}-$ tively, Fig. 6).

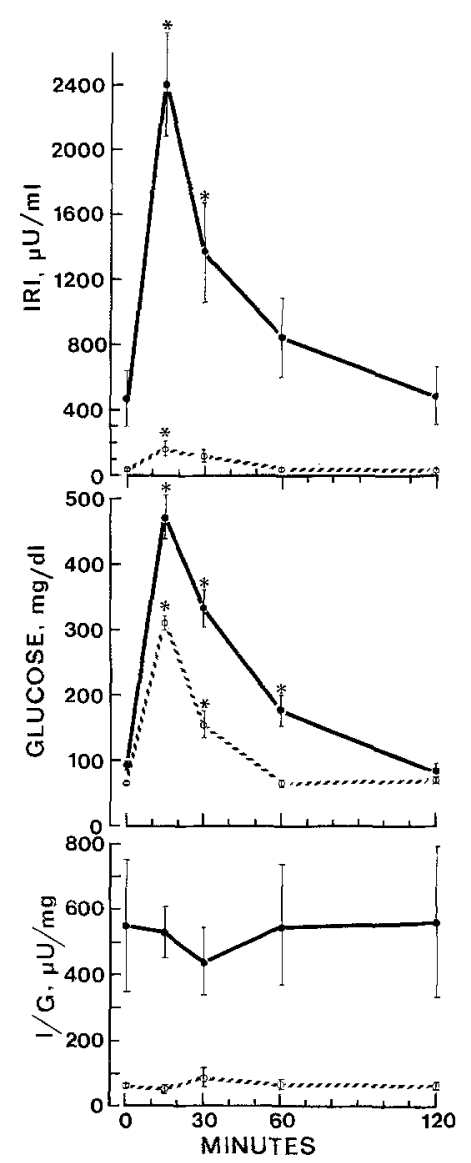

Fig. 2. Effects of glucose $(1.0 \mathrm{~g} / \mathrm{kg}$ body weight IV at time zero min) on serum IRI, glucose and $I / G$ ratio in 6 dogs when untreated $0----O$, and 1 day after the first injection of growth hormone - A value with an asterisk $\left({ }^{*}\right)$ placed above it differs significantly from the fasting value at 0 min ( $P$ range $<0.05$ $-<0.001)$

Table 2. Comparison of changes in serum IRI, glucose and $I / G$ ratio in the tests on 6 dogs before and during growth hormone treatment. The mean fasting $(0 \mathrm{~min})$ level and the rise over the fasting level at $15 \mathrm{~min}$ are shown

\begin{tabular}{|c|c|c|c|c|c|c|c|}
\hline \multirow[t]{2}{*}{ Test } & \multirow{2}{*}{$\begin{array}{l}\text { Growth } \\
\text { Hormone } \\
\text { Treatment } \\
\text { Days }\end{array}$} & \multicolumn{2}{|c|}{ Serum IRI $(\mu \mathrm{U} / \mathrm{ml})$} & \multicolumn{2}{|c|}{ Serum Glucose $(\mathrm{mg} / \mathrm{dl})$} & \multicolumn{2}{|c|}{ Serum $\mathrm{I} / \mathrm{G}(\mu \mathrm{U} / \mathrm{mg})$} \\
\hline & & $0 \min$ & $\begin{array}{l}\text { Rise at } \\
15 \text { min }^{a}\end{array}$ & $0 \mathrm{~min}$ & $\begin{array}{l}\text { Rise at } \\
15 \text { min }^{\mathrm{a}}\end{array}$ & $0 \min$ & $\begin{array}{l}\text { Rise at } \\
15 \mathrm{~min}^{\mathrm{a}}\end{array}$ \\
\hline Glucose IV & 1 & $468 \pm 172$ & $1932 \pm 362$ & $92 \pm 6$ & $380 \pm 33$ & $549 \pm 200$ & $n s^{b}$ \\
\hline Glucose IV & 0 & $38 \pm 5$ & $122 \pm 43$ & $66 \pm 2$ & $244 \pm 11$ & $57 \pm 7$ & ns \\
\hline Glucagon IV & 3 & $378 \pm 45$ & $398 \pm 87$ & $160 \pm 26$ & $114 \pm 36$ & $262 \pm 42$ & ns \\
\hline Glucagon IV & 0 & $24 \pm 4$ & $172 \pm 23$ & $74 \pm 8$ & $155 \pm 14$ & $33 \pm 7$ & $53 \pm 11$ \\
\hline Arginine IV & 5 & $418 \pm 84$ & $1340 \pm 127$ & $364 \pm 76$ & ns & $155 \pm 43$ & $350 \pm 129$ \\
\hline Arginine IV & 0 & $49 \pm 10$ & $167 \pm 56$ & $66 \pm 4$ & $32 \pm 14$ & $74 \pm 15$ & $156 \pm 67$ \\
\hline $\mathrm{Meal}^{\mathrm{c}}$ & 2 & $776 \pm 297$ & $1280 \pm 445$ & $120 \pm 16$ & ns & $790 \pm 380$ & ns \\
\hline Meal & 0 & $25 \pm 5$ & $18 \pm 6$ & $66 \pm 7$ & ns & $41 \pm 10$ & $\mathrm{~ns}$ \\
\hline
\end{tabular}

a Value at 15 min minus fasting value ( $\pm \mathrm{SE}$ of the difference): $\mathrm{P}$ range for these differences $<0.05-<0.001$

${ }^{\mathrm{b}}$ Not significant, $\mathrm{P}>0.05$

${ }^{\mathrm{c}}$ Mean for 5 dogs 

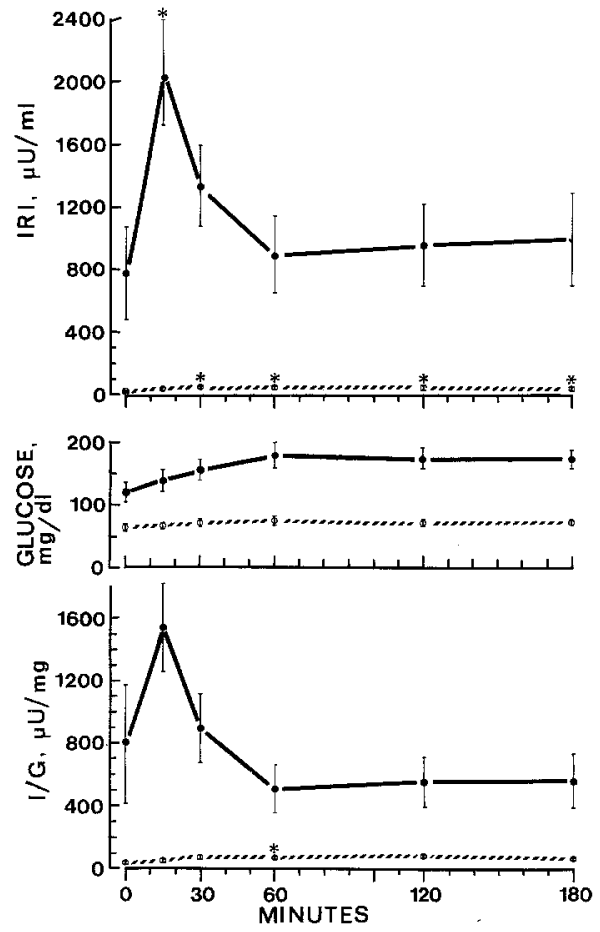

Fig. 3. Effects of a meal on serum IRI, glucose and $I / G$ ratio

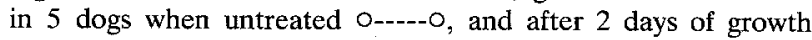
hormone treatment $\longrightarrow$. A value with an asterisk $(*)$ placed above it is significantly different from the fasting value at zero minutes ( $\mathrm{P}$ range $<0.05-<0.025$ )

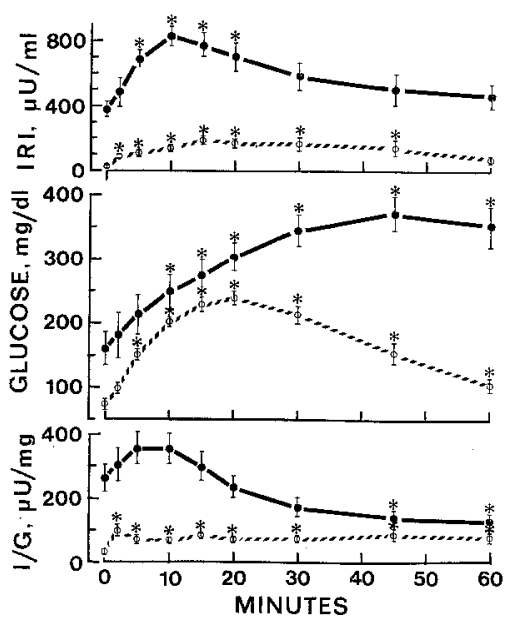

Fig. 4. Effects of glucagon $(0.1 \mathrm{mg} / \mathrm{kg}$ body weight $\mathrm{IV}$ at time 0 $\mathrm{min}$ ) on serum IRI, glucose and $\mathrm{I} / \mathrm{G}$ ratio in 6 dogs when untreated O-...-O, and after 3 days of growth hormone treatment - A value with an asterisk $\left(^{*}\right)$ placed above it is significantly different from the fasting value at $0 \mathrm{~min}$ ( $\mathrm{P}$ range $<0.05-$ $<0.001)$
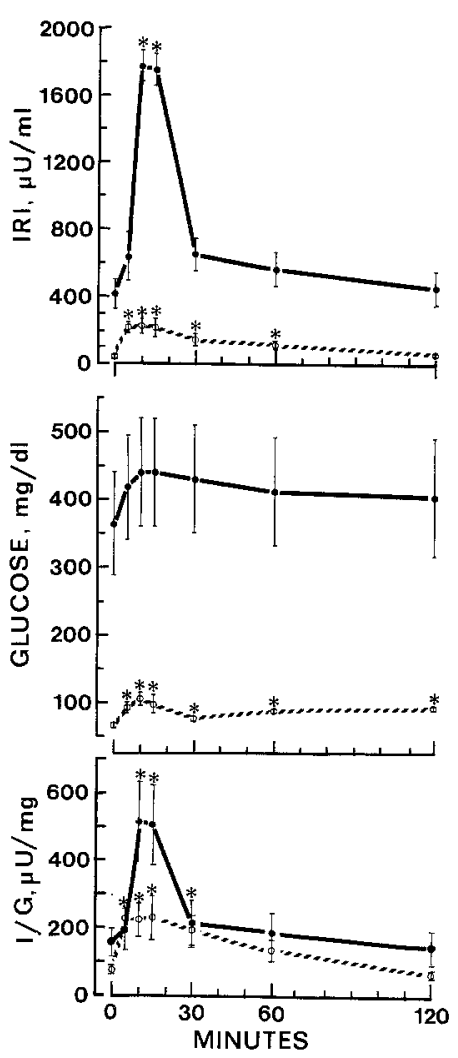

Fig. 5. Effects of arginine $(0.4 \mathrm{~g} / \mathrm{kg}$ body weight $I V$ at time $0 \mathrm{~min})$ on serum IRI, glucose and $I / G$ ratio in $6 \mathrm{dogs}$, when untreated $O_{-----O}$, and after 5 days of growth hormone treatment - A value with an asterisk $\left(^{*}\right)$ placed above it is significantly different ( $\mathrm{P}$ range $<0.05-<0.001$ ) from the fasting value at $0 \mathrm{~min}$

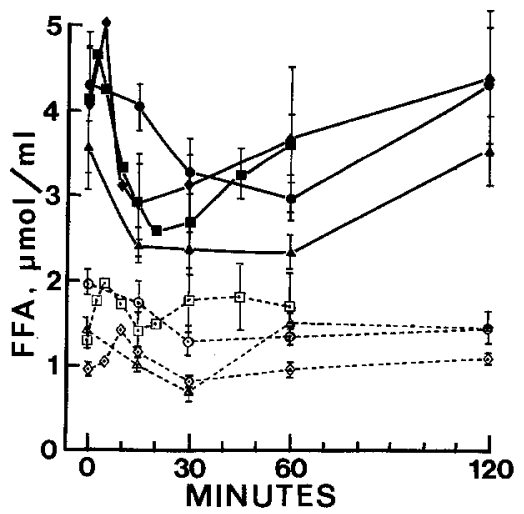

Fig. 6. FFA of serum in the control period, following IV injection of glucose $\triangle-\cdots--\triangle$, glucagon $\square----\square$, and arginine $\diamond----\diamond$, and following a meal $O \ldots \ldots$. The FFA values in these tests during growth hormone treatment are shown in the corresponding solid black symbols and continuous lines 
Table 3. The insulin content of the pancreas in 6 dogs given growth hormone hormone treatment for 6 days (somatotrophic diabetic) and in normal dogs

\begin{tabular}{|c|c|c|c|c|c|c|}
\hline \multirow[t]{2}{*}{ Dogs } & \multirow[t]{2}{*}{ (n) } & \multirow[t]{2}{*}{ Body Weight kg } & \multicolumn{4}{|l|}{ Pancreas } \\
\hline & & & Weight $\mathrm{g} / \mathrm{kg}$ body & IRI U/pancreas & IRI $\mathrm{mU} / \mathrm{g}$ pancreas & IRI $\mathrm{mU} / \mathrm{kg}$ body \\
\hline $\begin{array}{l}\text { Somatotrophic } \\
\text { diabetic }\end{array}$ & (6) & $18.2 \pm 1.0$ & $1.63 \pm 0.14$ & $9.1 \pm 3.7$ & $289 \pm 100$ & $472 \pm 179$ \\
\hline $\begin{array}{l}\text { Normal } \\
\mathrm{P}^{\mathrm{a}}\end{array}$ & (3) & $15.2 \pm 2.3$ & $2.20 \pm 0.14$ & $\begin{array}{l}101 \pm 20 \\
<0.001\end{array}$ & $\begin{array}{l}3423 \pm 1230 \\
<0.001\end{array}$ & $\begin{array}{l}7220 \pm 2240 \\
<0.001\end{array}$ \\
\hline
\end{tabular}

a Probability of difference between the values in the treated and normal dogs

\section{Response to a Meal}

Following the ingestion of a meal in the control period (Fig. 3) serum IRI increased relatively slightly but significantly (at $0 \mathrm{~min} 25 \pm 5$ and at 30-180 min range $47 \pm 6-56 \pm 7 \mu \mathrm{U} / \mathrm{ml}, \mathrm{P}$ range $<0.05-$ $<0.025$ ). Serum glucose was unchanged. The $\mathrm{I} / \mathrm{G}$ ratio increased slightly (at $0 \mathrm{~min} 41 \pm 9$ and at $30-120 \mathrm{~min}$ range $74 \pm 9-77 \pm 14 \mu \mathrm{U} / \mathrm{mg}: \mathrm{P}$ at 60 $\min <0.05$ ). After 2 days of growth hormone treatment and following the meal (Fig. 3) serum IRI rose in $15 \mathrm{~min}$ by $1280 \mu \mathrm{U} / \mathrm{ml}$ over the high fasting value $(\mathrm{P}<0.025)$. Serum glucose did not change significantly nor did the $\mathrm{I} / \mathrm{G}$ ratio. FFA decreased following the meal: during growth hormone treatment the fall at $30 \mathrm{~min}$ from the high fasting level was more pronounced than in the normal state $(-1.01 \pm 0.41$ and $-0.81 \pm 0.26 \mu \mathrm{mol} / \mathrm{ml}$ respectively, Fig. 6 ).

\section{Response to Glucagon}

Following glucagon IV in the normal state (Fig. 4) serum IRI rose maximally to 8 times the fasting value. Serum glucose rose to about thrice the fasting value. The $\mathrm{I} / \mathrm{G}$ ratio increased to a lesser extent (at 0 $\min 33 \pm 7$ and at $2-60 \mathrm{~min}$ range $70 \pm 8-99 \pm$ $18 \mu \mathrm{U} / \mathrm{mg}$ : P range $<0.05-<0.005$ ).

On repetition of the test at day 3 of growth hormone treatment (Fig. 4) serum IRI rose by about twice the normal extent (Table 2). The increases in serum glucose were comparable to those in the normal state up to $20 \mathrm{~min}$, but the rise continued to the end of the test period. The early change in the $I / G$ ratio was not significant, but after $30 \mathrm{~min}$ the ratio fell below the high fasting value (at $0 \min 262 \pm 42$ and at 45 and $60 \mathrm{~min} 138 \pm 24$ and $128 \pm 25 \mu \mathrm{U} /$ mg: $\mathrm{P}<0.05$ and $<0.025$ ). Serum FFA concentration was not significantly changed in this test except for a rise at $5 \mathrm{~min}$ in the normal state (Fig. 6).

\section{Response to Arginine}

Arginine IV in the normal state (Fig. 5) caused a prompt rise in serum IRI to 4 -fold the fasting value (at $0 \min 49 \pm 10$ and at 5-15 min range $216 \pm 55-$ $228 \pm 44 \mu \mathrm{U} / \mathrm{ml}: P$ range at 5-60 $\mathrm{min}<0.05-$ $<0.005)$. The rise in serum glucose was much less (1.5 times). The $\mathrm{I} / \mathrm{G}$ ratio increased to about thrice the fasting value (at $0 \mathrm{~min} 74 \pm 15$ and at $5-30 \mathrm{~min}$ $193 \pm 46-224 \pm 29 \mu \mathrm{U} / \mathrm{mg}: \mathrm{P}$ range $<0.05-$ $<0.001$ ).

At 5 days of growth hormone treatment the fasting serum IRI, glucose and $\mathrm{I} / \mathrm{G}$ ratio levels were elevated (to 8.5, 5.5 and 2.1 times the normal, respectively). After arginine IV (Fig. 5) serum IRI again rose rapidly to 4 -fold the fasting level: the increase was, however, 8 times greater in extent than in the untreated state (Table 2). Serum glucose did not change significantly. The $\mathrm{I} / \mathrm{G}$ ratio rose to thrice the fasting value: the increase was twice that in the untreated state. In this test in the normal state, FFA increased transiently at $10 \mathrm{~min}$, and during growth hormone treatment the seeming fall in FFA was not significant (Fig. 6).

\section{Comparison of the Responses}

For comparison of these responses to IV glucose, glucagon and arginine, the fasting values and the rises at $15 \mathrm{~min}$ are shown in Table 2 . In the normal state, the rises in serum IRI $(\mu \mathrm{U} / \mathrm{ml})$ were similar in the three tests, the rise in serum glucose was greatest in the glucose test, intermediate in the glucagon test and least in the arginine test. The rise in serum $I / G$ ratio was greater in the arginine test than in the glucagon test: no significant change occurred in the glucose test. During growth hormone treatment, the rise in serum IRI was greatest in the glucose test, also great in the arginine test and much less in the glucagon test. The rise in serum glucose had the same sequence in the three tests as in the normal state. A marked rise in the serum $\mathrm{I} / \mathrm{G}$ ratio occurred in the arginine test, but not in the glucagon and glucose tests. In response to a meal in the control period, the rise in serum IRI was slight, but in the treatment period, the rise almost equalled that due to arginine IV. In the glucose and meal tests during treatment there was a pro- 
nounced fall in FFA from the high initial levels associated with intolerance to glucose.

\section{Insulin Content of the Pancreas}

Six days from the first injection of growth hormone the IRI content of the pancreas was diminished to $6-9 \%$ of that in 3 untreated dogs that were given the same diet for 6 days (Table 3). The degree of the effect was related to the intensity of the somatotrophic diabetes in the individual dogs. Body weight increased by about 3\% in 2-5 days during the growth hormone treatment, then returned to the pretreatment level on the final day (Table 1). No change in mean body weight occurred in the control dogs in the six-day period.

\section{Discussion}

Evidence indicates that growth hormone can promote insulin secretion in man. The insulin secretory response to glucose was increased in cases of active acromegaly [21, 22]. Deficiency in the response in ateliotic dwarfism was restored towards normal by growth hormone treatment [23]. Administration of human growth hormone to subjects enhanced the response $[24,25,26]$. Bovine growth hormone treatment at high dosage had similar but more extensive effects in the dog [7].

The great and sustained elevation of the fasting blood IRI produced by growth hormone in the dog is associated with increased systemic delivery rate of insulin, without alteration in the fractional rate of disappearance of insulin and therefore may be attributed to increased rate of secretion of insulin under basal conditions [9]. The early rise in serum IRI during the treatment occurred before an appreciable increment in serum glucose. Within a day of growth hormone treatment in young dogs, a rise in serum IRI preceded change in serum glucose and FFA [27]. The stimulation of insulin secretion early in growth hormone treatment thus appears to be independent of change in glucose and FFA. Growth hormone added to the fluid perfusing the rat pancreas [28] or injected IV in the anaesthetized dog [29] rapidly elicits a pulse of insulin release: the effect is indicative of direct stimulation of the pancreatic islets. It is probable therefore that the sustained enhancement of insulin secretion by growth hormone treatment in the dog may be due to the combined action of continued direct stimulation of insulin secretion and to the participation of other stimulating factors, of which the hyperglycaemia may be one.
When blood glucose was independently raised by the rapid infusion of glucose after a day of growth hormone treatment, the augmented rise in serum IRI (about 16 times the normal rise) at high fasting IRI level (about 12 times the normal level) indicates that growth hormone magnified the stimulated secretion of insulin over the already elevated basal rate of secretion. In the normal response to the glucose load the $\mathrm{I} / \mathrm{G}$ ratio did not depart significantly from the fasting value. This tendency to maintain the $I / G$ ratio at the initial level also occurred in this test during growth hormone treatment, at a much higher initial value of the ratio. The results are indicative of close dependence of change in insulin secretion rate on change in glucose concentration in blood, and during growth hormone treatment of maintenance of the relation at a higher level.

The direct stimulation of insulin release by glucagon can be distinguished from the effect due to the rise in blood glucose [30,31]. The rise in the $\mathrm{I} / \mathrm{G}$ ratio that occurs in this test may be indicative of this independent action of glucagon on the pancreatic islets, since the ratio was not altered by glucose infusion. Growth hormone treatment augmented the IRI response to glucagon at a high fasting serum IRI level. The synergistic effect of glucose on the insulin secretory response to glucagon [30] suggests that the hyperglycaemia with growth hormone treatment may have enhanced the response.

In the normal state, the rise in serum IRI in response to arginine was similar to that due to glucagon and somewhat higher than that due to glucose. The rise in serum glucose in the arginine test was much less, however, than in the glucagon and glucose tests. Particularly noteable was the rise in the $\mathrm{I} / \mathrm{G}$ ratio in the arginine test which was thrice that in the glucagon test. The relation between the responses in the three tests in the dog agrees fairly well with the relation in healthy subjects [32] and supports the conclusions of these authors that the increases in blood glucose observed in arginine infusion cannot be the major cause of the increase in blood insulin and that the two effects can be separated. The administration of human growth hormone augments the insulin-release response to arginine in healthy subjects $[25,26]$. During growth hormone treatment in dogs (fifth day) arginine IV caused a great (3-fold) increase in serum IRI over the high fasting level (8.5fold the normal), indicating augmentation of the stimulated secretion of insulin over the already elevated basal secretion. The rise in the $\mathrm{I} / \mathrm{G}$ ratio was outstanding in the arginine test during growth hormone treatment, being double that which occurred in the normal state, while the ratio was not altered in the glucose test and a late fall occurred in the glucagon test. 
Reduction of the insulin content of the pancreas to less than $10 \%$ of normal by the growth hormone treatment may be due to such great stimulation of insulin secretion as to exceed the rate of formation of insulin.

These effects of growth hormone were probably nearly maximal: they appeared earlier and were of even greater extent than found previously in dogs under similar treatment $[7,9,10]$. The growth hormone preparations used were of comparable growthpromoting activity but from different sources. It appears probable that sensitivity to the effects of growth hormone was produced by long residence in the laboratory, with little exercise and a generous diet that led to adiposity. Related to these observations is the occurrence in human obesity of high blood insulin, increased insulin-release response to glucose and high incidence of diabetes $[22,31,33$, $34,35]$ and of similar characteristics in mice with spontaneous and induced obesity [36].

It can be recognised from these and other studies $[11,12,35]$ that growth hormone produces comparable effects in man and experimental animals, but that the effects may differ greatly in extent. The induction of somatotrophic diabetes, which is characterised in its early stages by hyperinsulinaemia, enhanced basal secretion of insulin and augmented secretion in response to stimulants appears so far to be unique among these effects.

Acknowledgements. The investigation was supported by the Medical Research Council of Canada, Grant No. 1186, the J. P. Bickell Foundation and the Canadian Diabetic Association. Dr. J. Pierluissi was granted Fellowships by the Universidad Central de Venezeula and the Consejo Nacional de Investigacions Cientificas y Tecnologicas, Venezuela. We thank Dr. Charles H. Best for his advice and are especially grateful to Dr. K. S. Rastogi for her aid. We are grateful for the donations of growth hormone from Dr. H. D. Bett of the Connaught Medical Research Laboratories, and from the Endocrine Study Committee, National Institute of Health, U.S. A., of glucagon from Dr. Mary A. Root, Eli Lilly Laboratories and of antibody reagents for immunoassay procedures from Dr. Strath Wilson and Dr. A. M. Fisher of the Connaught Medical Research Laboratories.

\section{References}

1. Kinash, B., MacDougall, I., Evans, M. A., Bryans, F. E., Haist, R. E.: Effects of anterior pituitary extracts and of growth hormone preparations on the islets of Langerhans and the pancreas. Diabetes 2, 112-121 (1953)

2. Martin, J. M., Akerblom, H. K., Garay, G.: Insulin secretion in rats with elevated levels of circulating growth hormone due to MtT-W15 tumor. Diabetes 17, 661-667 (1968)

3. Malaisse, W. J., Malaisse-Lagae, F., King, S., Wright, P. H.: Effect of growth hormone on insulin secretion. Am. J. Physiol. 215, 423-428 (1968)

4. Schatz, H., Katsilambros, N., Hinz, M., Voigt, K. H., Nierle, C., Pfeiffer, E. F.: Hypophysis and function of pancreatic islets. The effect of substitution with growth hormone and corticotrophin on insulin secretion and biosynthesis of proinsulin and insulin in isolated pancreatic islets of hypohysectomized rats. Diabetologia 9, 140-144 (1973)

5. Cotes, P. M., Reid, E., Young, F. G.: Diabetogenic action of pure anterior pituitary growth hormone. Nature 164, 209-211 (1949)

6. Campbell, J., Davidson, I. W. F., Snair, W. D., Lei, H. P.: Diabetogenic effect of purified growth hormone. Endocrinology 46, 273-381 (1950)

7. Campbell, J., Rastogi, K.S.: Growth hormone-induced diabetes and high levels of serum insulin in dogs. Diabetes 15, 30-43 (1966)

8. Altszuler, N., Rathgeb, I., Winkler, B., de Bodo, R. C., Steele, R.: Effects of growth hormone on carbohydrate and lipid metabolism in the dog. Ann. N. Y. Acad. Sci. 148, 441-458 (1968)

9. Campbell, J., Rastogi, K. S.: Actions of growth hormone: enhancement of insulin utilization with inhibition of insulin effect on blood glucose in dogs. Metabolism 18, 930-944 (1969)

10. Campbell, J., Rastogi, K. S.: Augmented insulin secretion due to growth hormone. Stimulating effects of glucose and food in dogs. Diabetes 15, 749-758 (1966)

11. Malaisse, W. J.: Hormonal and environmental modification of islet activity. In: D. F. Steiner, N. Freinkel (Eds.): Handbook of Physiology, Section 7, Endocrinology, Vol. 1, pp 237-260. Washington, D. C.: American Physiological Society $1972^{\circ}$

12. Merimee, T. J., Rabin, D.: A survey of growth hormone secretion and action. Metabolism 22, 1235-1251 (1973)

13. Pierluissi, J., Campbell, J.: Effects of growth hormone on serum insulin and responses to glucose, arginine and glucagon (Abstract). Fed. Proc. 32, 265 (1973)

14. Greenspan, F.S., Li, C.H., Simpson, M.E., Evans, H. M.: Bioassay of hypophyseal growth hormone: the tibia test. Endocrinology 45, 455-463 (1949)

15. Davis, B. J.: Disc electrophoresis II. Method and application to human serum proteins. Ann. N. Y. Acad. Sci. 121, 404-427 (1964)

16. Hales, C. N., Randle, P. J.: Immunoassay of insulin with insulin-antibody precipitate. Biochem. J. 88, 137-146 (1963)

17. Okuda, J., Okuda, G.: A rapid polarographic microdetermiantion of glucose with glucose oxidase. Clin. Chim. Acta 23, 365-367 (1969)

18. Itaya, K., Ui, M.: Colorimetric determination of free fatty acids in biological fluids. J. Lipid Res. 6, 16-20 (1965)

19. Davoreen, P. R.: The isolation of insulin from a single cat pancreas. Biochim. Biophys. Acta 63, 150-153 (1962)

20. Snedecor, G. W., Cochran, W. G.: Statistical Methods, Ed. 6. Ames, Iowa: Iowa State College Press 1967

21. Beck, P., Schalch, D.S., Parker, M. D., Kipnis, D.M., Daughaday, W. H.: Correlative studies of growth hormone and insulin plasma concentrations with metabolic abnormalities in acromegaly. J. Lab. Clin. Med. 66, 366-379 (1965)

22. Karam, J. H., Grodsky, G. M., Pavlatos, F. C., Forsham, P. H.: Critical factors in excessive serum-insulin response to glucose. Obesity in maturity-onset diabetes and growth hormone in acromegaly. Lancet 1965 I, 286-289

23. Merimee, T. J., Rabinowitz, D., Rimoin, D. L., McKusick, V. A.: Isolated human growth hormone deficiency. III Insulin secretion in sexual ateliotic dwarfism. Metabolism 17, 1005-1011 (1968)

24. Luft, R., Cerasi, E., Werner, S.: The effect of moderate and high doses of human growth hormone on the insulin response to glucose infusion in prediabetic subjects. Horm. Metab. Res. 1, 111-115 (1969)

25. Fajans, S. S., Floyd, J. C. Jr., Knopf, R. F., Conn, J. W.: Effect 
of amino acids and proteins on insulin secretion in man. Recent Prog. Horm. Res. 23, 617-662 (1967)

26. Pek, S., Fajans, S. S., Floyd, J. C., Jr., Knopf, R. F.: Clinical conditions associated with elevated plasma levels of glucagon. In: W. J. Malaisse, J. Pirart, J. Vallance-Owen (Eds.): Diabetes, Proc. Eighth Congress, International Diabetes Federation, Brussels. Excerpta Medica Int. Congr. Series 312, 207-213 (1974)

27. Pierluissi, J., Oliveira, A. de Maksimenko, A., Espinosa, I.: Effect of growth hormone on insulin secretion in young dogs (Abstract). Proc. Int. Union Physiol. Sci. 13, 598 (1977)

28. Pek, S., Tai, T.-Y., Crowther, R., Fajans, S. S.: Glucagon release precedes insulin release in response to common secretagogues. Diabetes 25, 764-770 (1976)

29. Sirek, A., Vranic, M., Sirek, O. V.: Effect of a single somatotropin (STH) injection on plasma insulin and glucagon levels in the dog. Proc. Int. Union Physiol. Sci. 12, 701 (1977)

30. Samols, E., Marri, G., Marks, V.: Interrelationship of glucagon, insulin and glucose. The insulinogenic effect of glucagon. Diabetes 15, 855-866 (1966)

31. Crockford, P.M., Hazzard, W. R., Williams, R. H.: Insulin response to glucagon. The opposing effects of diabetes and obesity. Diabetes 18, 216-224 (1969)

32. Floyd, J. C. Jr., Fajans, S. S., Pek, S., Thiffault, C. A., Knopf, R. F., Conn, J. W.: Synergistic effect of essential amino acids and glucose upon insulin secretion in man. Diabetes 19, 109-115 (1970)
33. Karam, J. H., Grodsky, G. M., Forsham, P. H.: Excessive insulin response to glucose in obese subjects as measured by immunochemical assay Diabetes 12, 197-204 (1963)

34. Perley, M., Kipnis, D. M.: Plasma insulin responses to glucose and tolbutamide of normal weight and obese diabetic and nondiabetic subjects. Diabetes 15, 867-874 (1966)

35. Rabinowitz, D.: Some endocrine and metabolic aspects of obesity. Annu. Rev. Med. 21, 241-258 (1970)

36. Stauffacher, W., Lambert, A. E., Vecchio, D., Renold, R. E.: Measurement of insulin activities in pancreas and serum of mice with spontaneous ("obese" and "New Zealand obese") and induced (GTG) obesity and hyperglycemia and considerations of the pathogenesis of the spontaneous syndrome. Diabetologia 3, 230-240 (1967)

Received: September 30, 1977,

and in revised form: April 27, 1978

Dr. J. Campbell

Department of Physiology

Medical Sciences Building

University of Toronto

Toronto, Ontario M5S 1A8

Canada 